\title{
Ethephon for induction of multiple tubers in water yam (D. alata) $)^{1,2}$
}

\author{
Ricardo Goenaga, Héber Irizarry, and Edmundo Rivera ${ }^{3}$
}

\begin{abstract}
Yam cultivar Gunung (Dioscorea alata) is resistant to anthracnose ( $\mathrm{Co} /$ letotrichum gloeosporioides Penz.). It has an extraordinary yield potential. Yet its acceptability has been limited because of the frequent production of large-sized and off-shaped tubers which are difficult to market. Local growers will increasingly accept this cultivar if tuber size can be reduced without an undue loss in yield. A study was conducted to determine whether ethephon [(2-chloroethyl) phosphonic acid] can induce multiple stem sprouting and hence multiple tuber production as a means of reducing tuber size and improving shape. Head, middle, and tail tuber sections were treated with a $1 \%$ ethephon solution and planted in the field. The ethephon treatment significantly increased stem sprouting in the middle and tail sections but not in the head section. A significant reduction in mean tuber weight was observed in all treated sections. However, this reduction was compensated for by a significant increase in the number of tubers produced per plant. The hormone treatment did not significantly affect fotal yield but did lead to more production of uniform tubers. Mean yield of marketable tubers was $73,123 \mathrm{~kg} / \mathrm{ha}$.
\end{abstract}

\section{RESUMEN}

Inducción múltiple de fubérculos con efefón en el ñame de agua (D. alata).

Se realizó un estudio de campo para ver si el compuesto etefón puede inducir tallos y tubérculos múltiples en el ñame Gunung y redundar en tubérculos más pequeños, uniformes y lisos.

Secciones de la cabeza, el medio y el rabo se trataron con una solución de etefón antes de sembrarlas. El tratamiento con etefón aumentó significativamente la producción de tallos primarios en las secciones del medio y el rabo, pero no en las de la cabeza. El peso medio de los tubérculos cosechados de las secciones tratadas disminuyó significativamente. Sin embargo, este efecto lo compensó un aumento significativo en el número de tubérculos por planta. Aunque la aplicación de etefón no afectó los rendimientos totales, la producción de tubérculos uniformes aumentó en las semillas tratadas. La medida en rendimiento comercial para todos los tratamientos fue de $73,123 \mathrm{~kg} . / \mathrm{ha}$.

'Manuscript submitted to Editorial Board 20 September 1988.

'This paper covers work carried out cooperatively between the Agricultural Research Service-USDA and the Agricultural Experiment Station, University of Puerto Rico, Río Piedras, P. R.

'Research Plant Physiologist, Research Horticulturist, and Agronomist, respectively, USDA ARS, Tropical Agriculture Research Station, Mayagüez, P. R. 


\section{INTRODUCTION}

True yams (Dioscorea spp.) are an important food staple in the humid and subhumid tropics. The tubers accumulate large quantities of carbohydrates which provide energy.

In 1986 , yam production in Puerto Rico increased to $12,000,000 \mathrm{~kg}$ with an annual farm value of $\$ 6$ million. During the same year 2,000,000 $\mathrm{kg}$ of yam tubers were imported. Thus, there is added incentive for increasing local production (1). A major constraint for expansion, however, is their susceptibility to leaf anthracnose caused by Colletotrichum gloeosporioides Penz. and other foliar diseases. Some high yielding water yams ( $D$. alata) introduced in the late 1960 's (4) and recently reported to have resistance to foliar diseases (2) and viruses can expand local production.

Among these yams, cultivar Gunung (P.I. No. 390102) is a potential variety. Its acceptance, however, has been restricted because of the frequent production of over-sized and off-shaped tubers (4). These large tubers are often difficult to market. When they are marketed in pieces, spoilage from oxidation and fungal growth contribute to losses and a decrease in shelf life. If tuber size could be reduced and the shape could be improved without detriment to yield, handling and marketing would improve materially.

Little is known about the effects of plant growth regulators on tuber formation. Martin and Cabanillas (3) disrupted the bud dormancy period of yam tubers and induced stem sprouting by treating seedpieces with ethephon [(2-chloroethyl) phosphonic acid]. Their results confirm studies with potato tubers in which ethylene-releasing substances such as ethephon have induced similar responses (6). Conclusive data, however, are lacking on whether ethephon can induce multiple stem sprouting and hence multiple yam tuber production as a means to reduce tuber size.

The main objective of this work was to determine whether ethephon could induce multiple sprouting in tuber sections of $D$. alata Gunung and its effect on tuber size, shape and yield.

\section{MATERIALS AND METHODS}

The experiment was conducted at the Corozal Substation, Corozal, P. R. The soil (Corozal) is a clayey, mixed isohyperthermic Aquic Tropudults on a $15 \%$ slope. It has a $3 \%$ organic matter content and a $\mathrm{pH}$ of 5.3. Cation exchange capacity is $16 \mathrm{meq} / 100 \mathrm{~g}$ of soil and exchangeable bases are $11 \mathrm{meq} / 100 \mathrm{~g}$ of soil.

One week before planting, tubers of $D$. alata cv. Gunung were sectioned into heads, middles, and tails and the pieces treated with calcium hydroxide to speed suberization. After 24 hours, the propagating mate- 
rial was placed in perforated bags and submerged in a $1 \% \mathrm{v} / \mathrm{v}$ Ethrel $^{4}$ (ethephon) solution for $15 \mathrm{~min}$. A check treatment containing seedpieces from all tuber sections was submerged in water for the same period of time.

The factorial set of treatments consisting of two levels of ethephon $(0$, or check, and $1 \%)$ and three tuber sections (heads, middles, and tails) were planted in the field in a randomized complete block design with four replications.

On 17 June 1987 seedpieces, each weighing about $200 \mathrm{~g}$, were planted $0.3 \mathrm{~m}$ apart in plots with two non-ridged rows spaced $1.5 \mathrm{~m}$ apart. There were 24 plots, each with 20 seedpieces. Wire trellises about $2 \mathrm{~m}$ high were provided for vine support. The experimental plots received 2,200 $\mathrm{kg} / \mathrm{ha}$ of a $10-5-20$ fertilizer supplemented with $33 \mathrm{~kg} / \mathrm{ha}$ of a mixture of $6 \% \mathrm{Mg}, 7.7 \% \mathrm{Mn}, 4.8 \% \mathrm{Cu}, 7 \% \mathrm{Fe}, 8 \% \mathrm{Zn}$, and $2.5 \% \mathrm{~B}$, at 1 and 4 months after planting. Weed growth was suppressed with a pre-emergence application of ametryn [2-(ethylamino)-4-isopropylamino-6-methylthio-striazine] at the rate of $4.5 \mathrm{~kg}$ a.i./ha. Occasionally, plots were hand weeded as needed. One month after planting, nematodes and soil insects were controlled with a single band application of aldicarb [2-methyl-2(methylthio) propionaldehyde 0-(methylcarbamoyl) oxime)] at the rate of $3.0 \mathrm{~kg}$ a.i./ha. Three foliar sprays of benomyl [methyl 1 (butylcarbamoyl)-2-benzimidazole-carbamate] at the rate of $.56 \mathrm{~kg}$ a.i./ha were applied as a preventive measure against foliar diseases.

Eight months after planting, yams from each plot were harvested and classified by size and shape into four categories: marketable tubers, including large and fully deformed; slightly deformed; round and uniform; and small non-commercial tubers (fig. 1). The total number of main stems and tubers were recorded for each of these categories. Tubers were then weighed.

\section{RESULTS AND DISCUSSION}

The treatments that received ethephon exhibited a significant increase in the number of main stems that sprouted per seed piece (table 1). The induction of multiple stem sprouting depended on the tuber section as observed by the significant hormone treatment $\times$ tuber section interaction. Middle tuber sections treated with ethephon produced a significantly higher number of stems than those from head sections, as follows.

\footnotetext{
TTrade names in this publication are used only to provide specific information. Mention of a trade name does not constitute a warranty of materials by the USDA/ARS, nor is this mention a statement of preference over other materials.
} 


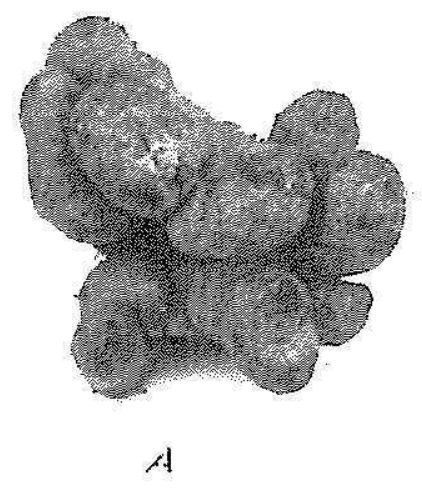

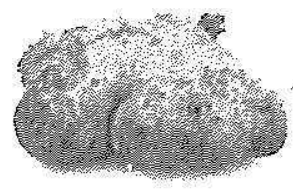

B

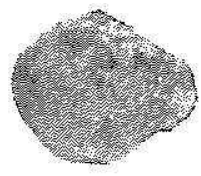

C

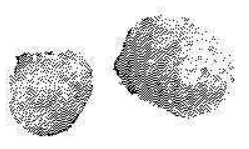

D

FrG. 1.-Classification of yam tubers (D. alata cv. Gunung) by size and shape. (A) large and fully deformed; (B) slightly deformed; (C) round and uniform; (D) small and non-commercial.

\begin{tabular}{lcc}
\multirow{2}{*}{ Tuber section } & \multicolumn{2}{c}{ Treatments } \\
\cline { 2 - 3 } & $\begin{array}{c}\text { Ethephon } \\
\text { No. of stems/seed piece }\end{array}$ \\
\hline Middle & 6.9 & 4.2 \\
Tail & 5.7 & 3.6 \\
Head & 5.0 & 5.0
\end{tabular}

Differences, however, were not significantly greater from the tuber tail sections. As compared with the check, treated middle and tail sections produced a significantly greater number of stems.

The application of ethephon to pre-plant seedpieces resulted also in a significant decrease in individual tuber weight. The reduction in mean

TABLE 1.-Mean square values for the various parameters studied in ethephon treated yams.

\begin{tabular}{lcccc}
\hline Source of variation & Stem/plant & Tuber/plant & Weight/tuber $\left(\mathrm{X} 10^{*}\right)$ & Yield $\left(\mathrm{X} 10^{\circ}\right)$ \\
\hline Hormone treatment & $15.22^{* * *)}$ & $5.38^{* * *}$ & $379.5^{* *}$ & $168.8^{\mathrm{NS}}$ \\
Tuber section & $1.72^{\mathrm{NS}}$ & $0.93^{\mathrm{NS}}$ & $24.6^{\mathrm{NS}}$ & $356.6^{\mathrm{NS}}$ \\
$\begin{array}{l}\text { Hormone treatment } \times \\
\quad \text { tuber section }\end{array}$ & $4.04^{*}$ & $1.05^{\mathrm{NS}}$ & $11.8^{\mathrm{NS}}$ & $4386.2^{\mathrm{NS}}$ \\
\hline
\end{tabular}

1: $:$ : $:$ Significant at $5 \%$ level;

* Significant at $1 \%$ level.

is Nonsignificant.

${ }^{5}$ Within a row or column, LSD $.05=1.55$ stems/seedpiece. 
tuber weight, however, was compensated for by a significant increase in the number of tubers produced per plant (tables 1 and 2 ).

The hormone did not affect total yield (table 1). The overall yield mean for the ethephon and check treatments was $78,352 \mathrm{~kg} / \mathrm{ha}$ (table 2).

Table 3 shows tuber yield after harvest and classification by size and shape. A substantial reduction in yield of deformed tubers was observed for all tuber sections treated with ethephon. Except in the head section, this response was accompanied by an increase in the yield of slightly deformed and uniform tubers. As compared to the check, ethephontreated middle sections produced $17 \%$ fewer deformed tubers, whereas these sections exhibited a 49 and $29 \%$ yield increase for slightly deformed and uniform tubers (table 3 ). A similar response was observed for treated tails except that in this case, most of the yield increase was observed in uniform tubers. Regardless of the tuber section, the hormone treatment always increased the weight of small non-marketable tubers.

The high yield performance and anthracnose tolerance exhibited by the Gunung cultivar confirmed the commercial potentials of this yam. Under proper management, including foliar sprays every 3 weeks for the control of anthracnose, D. alata cv. Smooth Statia yielded $27,760 \mathrm{~kg} / \mathrm{ha}$ of marketable tubers at the Corozal Substation (5). In this study, preventive fungicide was applied only three times. The yield of marketable tubers for all treatments averaged $73,123 \mathrm{~kg} / \mathrm{ha}$. This is the highest report of yam tuber production in Puerto Rico.

The use of the Gunung cultivar should be encouraged. Moreover, use of ethephon seed treatment should receive additional study to determine its potential in intensive commercial yam production.

\section{LITERATURE CITED}

1. Anonymous, 1986. Boletin semestral de estadísticas agrícolas enero-junio y julio-diciembre, Oficina de Estadísticas Agrícolas, Departamento de Agricultura, Santurce, Puerto Rico.

2. Hepperly, P. R. and F. Vásquez, 1989. Tropical yam (Dioscorea spp.) performance in western Puerto Rico. J. Agric. Univ. P. R. 73 (2):

TABLE 2.-Effect of ethephon application on yield components and total yield from three sections of the yam tuber

\begin{tabular}{|c|c|c|c|c|c|c|}
\hline \multirow[b]{2}{*}{ Tuber section } & \multicolumn{2}{|c|}{ Mean tuber weight } & \multicolumn{2}{|c|}{ Tuber/plant } & \multicolumn{2}{|c|}{ Total yield } \\
\hline & Check & Ethephon & Check & Ethephon & Check & hephon \\
\hline & \multicolumn{2}{|r|}{$g$} & \multicolumn{2}{|c|}{ No. } & \multicolumn{2}{|c|}{$\mathrm{kg} / \mathrm{ha}$} \\
\hline Head & 999 & 731 & 4.3 & 4.4 & 90,052 & 68,069 \\
\hline Middle & 884 & 716 & 4.1 & 5.4 & 76,823 & 83,132 \\
\hline Tail & 1070 & 751 & 3.3 & 4.8 & 76,206 & 75,828 \\
\hline Average $^{1}$ & 984 a & $733 \mathrm{~b}$ & $3.9 \mathrm{a}$ & $4.9 \mathrm{~b}$ & $81,027 \mathrm{a}$ & $75,676 \mathrm{a}$ \\
\hline
\end{tabular}

1 Means in rows, followed by a common letter do not differ significantly at the $1 \%$ probability level. 


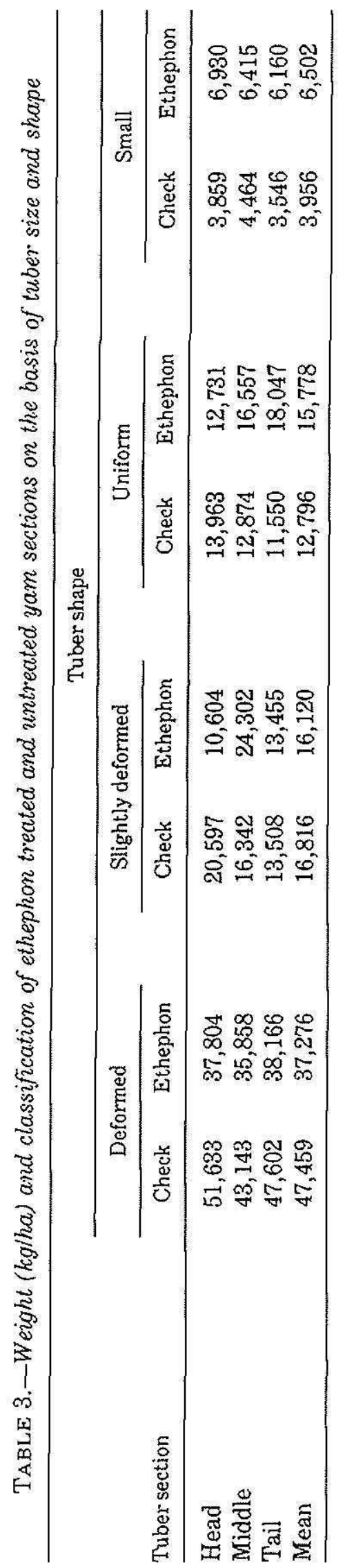


3. Martin, F. W. and E. Cabanillas, 1976. Stimulating the sprouting of yam tubers with ethephon. J. Agric. Univ. P. R. 60 (4): 592-96.

4. __ and H. Delpin, 1978. New, superior varieties of Dioscorea alata, the Asian greater yam. J. Agric. Univ. P. R. 62 (1): $64-75$.

5. Rodriguez-García, J., F. Abruña and H. Irizarry, 1983. Spraying for leaf spot and liming increase yam (Dioscorea alata L.) yield. J. Agric. Univ. P. R. 67 (3): 286-92.

6. Salisbury, F. B. and C. W. Ross, 1985. Growth Response to Temperature pp. 409-25. In. W. A. Jensen (Ed), Plant Physiology. Wadsworth Publishing Co., Inc., Belmont, CA. 